\title{
Employing Gamification Methods to Increase Customer Engagement in Digital Marketing
}

\author{
Gowtham ashirvad kumar, A. Ravi kumar
}

\begin{abstract}
As "Gamification" quickly becomes a hot topic across industries and academia, it deserves more thorough study through qualitative and quantitative research. There was a definite feeling of infancy of gamification, be it the definition of gamification or the effectiveness of gamification. This document provides a survey of this recent phenomenon of "gamification": a concept that has been applauded as a "game changing layer" and derided as a "useless buzzword". It provides a comparative review of different schools of thoughts on the effectiveness of applying game mechanics to non-game contexts. Both industry implementations and academic research is reviewed and analyzed. Most of gamification thought leaders agree that the current state of gamification is mainly focus on extrinsic rewards. While some see the bigger potentials of sustainable gamification with deeper researches in the intrinsic rewards from good game designs.
\end{abstract}

Keywords: Internet, Marketing, Digitization, Digital Marketing

\section{INTRODUCTION}

Gamification is the idea of applying game mechanics, game plan procedures or incorporating Big Data in a manner that is pertinent to your computerized advertising measurements, Return on Investment (ROI) and objectives. It very well may be utilized by incorporating applications, devices or straightforward yet creative procedures with your online life promoting efforts. [1],[3],[5]

The thought is to enable brands and their end clients to urge them to have continuous discussions and commitment with you.

Digital marketing is changing. The digital era only begins with millennials. The generation after (sometimes referred to as Generation $\mathrm{Z}$ or the generation) will have even greater demands on digital marketing. It won't be enough to simply engage in social media, we will have to adapt if we want to succeed.

Gamification could be that method of adaptation. Gamified content gives millennials a form of interaction that they don't often see and it gives this new generation the interaction they will demand.

Revised Manuscript Received on July 22, 2019.

Gowtham ashirvad kumar, Department of MBA, Bharath Institute of Higher Education and Research, Chennai, India.

Email: kgowthamaashirwad123@gmail.com

Dr . A. Ravi kumar, Department of THM, Bharath Institute of Higher

Education and Research, Chennai, India

Email: ravikumar.th@gmail.com

\section{NEED FOR THE STUDY}

1. Gamification is gradually turning into a power in advanced advertising, however you might address whether it is vital for your organization.

2. Possibly you think it is too huge of a speculation, perhaps you don't have the assets you have to deliver it. Whatever your reasons, you might need to rethink. [2 ],[4],[6]

3. Investigate these five reasons why gamification is the eventual fate of computerized advertising.

\section{SCOPE OF THE STUDY}

Games are ground-breaking. They engage us. They build up our preferences, and once in a while our characters as well. Since the beginning, they show us the world.

It was inevitable, at that point, before computerized advertisers began investigating the open doors accessible through the gamification of their channels. This article investigates a portion of the types of gamification in computerized promoting, and offers a few hints to remove for your very own showcasing exercises.

\section{RESEARCH DESIGN}

These days organizations over all spaces are utilizing gamification strategies to expand client commitment and loyalty,inspire their representatives, produce buzz among customers,enhance over all client experience. This techniques will inturn increment the business profit.Gamification encourages client to be associated more with the item which inturn builds client devotion. [7],[ 9] ,[11]

These models, which length over different verticals, item types, and gamification techniques, demonstrate to us that gamifying our procedures prompts expanded transformations, paying little heed to industry or group of spectators. It might be said, gamification is tied in with transforming clients into dynamic "co-makers" - charming them while additionally reassuring their connection and individual information.

A portion of the
gamification strategies than
can expand changes for
$\begin{aligned} & \text { Published By: } \\ & \text { Blue Eyes Intelligence Engineering } \\ & \text { \& Sciences Publication }\end{aligned}$




\section{Employing Gamification Methods to Increase Customer Engagement In Digital Marketing}

business are

1. Prizes and Rewards for Social Sharing - Discount coupons for social sharing

\section{Leaderboard - Leaderboard with rewards, badgesetc}

3. Timing Urgency - Eg Discount commencement clock appeared with offers

To make fruitful combination of gamification,allow clients to incorporate/customize/coordinate objectives with your product,allow them share/gloat about their achievement's. [8],[10],[12]

Approaches to add gamification to advertising methodology:

advertising pattern going ahead and, on the off chance that anything, is increasing more consideration as a perfect method to make commitment with a customer group of spectators. That is on the grounds that the idea of playing a game and potentially winning something invigorates the innovative, perky and aggressive soul in basically we all.

Gamification is fun - yet it's something beyond perusing words on a screen or viewing a video. The procedure includes an approach to improve abilities or show signs of improvement at something, in addition to it includes some sort of prize. [13], [15],[17]

For advertisers, gamification is an approach to stick out and utilize that passionate high of winning so as to finalize the negotiations on selling an item or administration. The utilization of gamification is paramount for the client and may feel slanted to share how they did in ongoing interaction with their groups of friends.

Utilizing gamification to expand the measure of time a purchaser spends in your application can raise their commitment level with your image. This goes far toward impacting their buy choices sooner rather than later.

Here are a few hints on how you can fuse gamification into your own advertising technique.

1. Know your crowd. Continuously begin with your intended interest group to figure out what sort of game may speak to your clients. On the off chance that you don't take a gander at this angle first, you may not connect with them to get the arrival you're chasing. A millennial group of spectators presumably doesn't care for a similar kind of ongoing interaction as a 40-something-year-old. In the event that you are going to utilize a test or random data position for your game, at that point consider your group of spectators' age with the goal that it incorporates applicable inquiries they could reply. In the event that your group of spectators includes a bigger statistic, you could join gaming components and important inquiries to speak to an increasingly broad statistic. [14],[16], [18]

\section{Results of the Nike+ Fuelband}

Before the finish of 2013 we saw 11 million Nike Fuelband players.

\section{Gamified Marketing Conclusion}

The utilization of gamified strategies is an amazing procedure for organizations to help the closeout of their items.

The above models show imaginative game structure, yet in addition the final products of joyfully drew in clients who, much of the time were excited to impart their encounters to their loved ones.

Care must be taken in applying gamification to one's own image. Organizations should know that gamification isn't a panacea. The experience must be arranged cautiously. The general plan requires specific skill that frequently depends on models.

\section{Gamification Marketing Examples}

Organizations need innovative advertising procedures to spread their organization message and advance their image. Gamification has turned into a well known methodology to arrive at buyers on the web and through associated cell phones. Gaming methods, for example, rivalry, positioning records, scoring frameworks, and motivations - are utilized to pull in clients with the general objective of structure brand dedication, making associations, and giving clients motivation to hold coming back to the brand and buy items and administrations. The focal goal of gamification as a showcasing apparatus is to support deals and increment benefit. These client arranged games have benefits that impel organizations closer to arriving at their destinations. They help in gathering client information, expanding commitment, boosting the organization brand and advancing recurrent business. The accompanying models show how significant organizations are effectively utilizing gamification promoting.

\section{M\&M's Eye-Spy Pretzel}

At the point when M\&M propelled a pretzel-enhanced form of their sweet, they utilized gamification and internet based life as a showcasing technique to advance their new item. The straightforward and modest procedure included an eye-spy game that was distributed on the brand's Facebook page. They posted a realistic comprising of many, multi-hued $\mathrm{M} \& \mathrm{M}$ confections and provoked their adherents and purchasers to locate a modest "pretzel fellow" tucked away among the confections. The game rapidly became famous online. The Eye-Spy Pretzel game got more than 25,000 preferences, 6,000 offers, and 10,000 remarks.

My Starbucks Rewards

Starbucks applies gamification strategies through their reliability program My Starbucks Rewards 
as an approach to expand client commitment and guarantee rehash business. Clients who become Starbucks Rewards individuals get impetuses, for example, free nourishment and beverages, and clients get focuses or "stars" with each buy. Clients would then be able to reclaim these stars for explicit things or prizes. Other interesting prizes, for example, a free birthday drink and free refills, become accessible as clients acquire more stars. The individuals who arrive at gold status remain to receive the best benefits. In this model, Starbucks gives motivations to gives purchasers a feeling of accomplishment and fortifies that in the event that they are faithful to the organization, they will be remunerated. [19],[21],[23]

\section{Chipotle Love Story Game}

Chipotle propelled a memory game dependent on their short film "A Love Story," wherein clients should coordinate genuine fixings together while maintaining a strategic distance from the utilization of included hues and flavors. Players are compensated with a get one-get sans one coupon for any nourishment thing. Helpfully, clients can play the game and get compensates all on their cell phones. The reward urges shoppers to play the game, remain connected with the organization, and buy more, while the game itself fortifies the brand message of utilizing solid, genuine fixings rather than fake hues and flavors. This is another gaming model that gives a chance to clients to associate with the brand while carrying consideration and buzz to the organization. [20],[22],[24]

Nike

The customized wellness following Nike+ and Fuelband embellishments take into account Nike to interface with their clients while gathering profitable data about them. The individual information they gather is helpful for upgrading their focused on substance showcasing efforts. Nike+ Fuelband gives clients motivators for utilizing the athletic GPS beacons to go up against others while running and working out. The NikeFuel application can be connected to web based life, which empowers clients to share and think about achievements. Trophies and identifications are granted to the individuals who arrive at achievements and accomplish athletic achievements, which further urges shoppers to utilize their items and look for more rewards. [25],[27],[29]

\section{Target's Wish List}

Target utilized gamification showcasing that was centered around youngsters with their Wish List application. They joined gamification with their Target Registries innovation to make an intelligent shopping list. Intended for the Christmas season, youngsters explore through a 3D vivified game that happens in Target's Toy Factory. They simplified wanted toys to assemble their vacation list of things to get and afterward send the finished rundown to Santa. The game was displayed as a fun path for kids to make their lists of things to get, and it's a simple route for guardians to purchase their kids endowments and offer blessing thoughts with different relatives. The execution of the application was effective with the underlying dispatch creating roughly 75,000 downloads. Through the span of the Christmas season there were in excess of 100,000 lists of things to get made up of 1.7 million complete things speaking to an all out deals capability of $\$ 92.3$ million.

Gamification advertising has taken off with the expanded utilization of the Internet, online networking, and portable innovation. Games fixated on an item or administration give a chance to clients to interface with and become acquainted with a brand. Organizations who incorporate parts of gaming into their showcasing techniques will locate that basic and frequently economical games can prompt expanded benefits and more noteworthy web-based social networking portion of voice. [26],[28],[30]

\section{V.RESULTS AND DISCUSSION}

Gamification has risen as a conspicuous pattern and effect such a large number of zones of business/society though exists numerous chances and dangers. There was a positive sentiment of outset of gamification, be it the meaning of gamification or the viability of gamification, there are banters from various regions of business. The greater part of gamification thought pioneers concur that the present condition of gamification is basically center around outward rewards, for example, focuses, identifications and leader boards, and this oddity of straightforward gamification will have its viability in client commitment before the curiosity worn off. Numerous likewise observe the greater possibilities of manageable gamification with more profound inquires about in the inherent prizes from great game structures. Sebastian Deterding even present the expression "gameful structure" (plan for gameful encounters) as a potential option in contrast to "gamification". [31],[33]

\section{CONCLUSION}

Be it "gamification" or "gameful structure", the discussion and the above writing overviews warrant more extensive scholastic research in this interdisciplinary zone that scaffolds HCI and game examinations and different fields to contemplate a wide scope of gamified applications. The real remove of perusing the discussions of gamification is that, this is a field overflowing with tales however minimal hard information. The fundamental focal point of the examination isn't whether gamification is fortunate or unfortunate, yet does it work or not.

\section{REFERENCES}

1) BharthVajan R., Ramachandran S.,Psychographic dimensions of training,2016,International Journal of Pharmacy and Technology,V-8,I-4,P-23727-23729

2) Balakrishnan P., Bharthvajan R.,A study on human resource planning in hospitals in Chennai City,2014,International Journal of Applied Engineering Research,V-9,I-22,P-7503-7507

3) Priyadarsini P., Bharthvajan R.,Role of emotional intelligence training programme in reducing the stress of the nurses,2014,International Journal of Applied Engineering Research,V-9,I-22,P-7411-7421

4) Kerinab Beenu G., Bharthvajan R.,Empirical analysis on the cosmetic buying behavior of young women in South India,2014,International Journal of Applied

Research,V-9,I-22,P-7361-7366

5) Balakrishnan P., Bharthvajan R.,Whistling in the 


\section{Employing Gamification Methods to Increase Customer Engagement In Digital Marketing}

wind,2014,International Journal of Applied Engineering Research,V-9,I-22,P-7586-7593

6) Krishnan B., Peter M.,Health hazards of Indian Bpo employee-an alarming issue,2014,International Journal of Applied Engineering Research,V-9,I-22,P-7336-7341

7) Kerinab Beenu G.H., Peter M.,Role of insurance in economic development,2014,International Journal of Applied Engineering Research,V-9,I-22,P-7532-7539

8) Balakrishnan P., Peter M., Priyadarsini P.,Efficiency of safety measures for wellbeing of employees in manufacturing industry,2014,International Journal of Applied Engineering Research,V-9,I-22,P-7376-7382

9) Anbarasi M., Praveen Kumar S.,Online sales promotions of herbal product and its effectiveness towards tanisha.com,2019,Indian Journal of Public Health Research and Development,V-10,I-1,P-195-200

10) Anbarasi M., Praveen Kumar S.,Various online marketing and promotions strategies to improve the validation towards the organic products in the pharmaceutical sectors,2019,Indian Journal of Public Health Research and Development,V-10,I-1,P-263-269

11) Loganathan R., Praveen Kumar S.,Grievance handling a key factor for solving issues of employees in an organization,2014,International Journal of Applied Engineering Research,V-9,I-22,P-7483-7491

12) Loganathan R., Praveen Kumar S.,Study on preference of private labe brands in super and Hypermarkets,2014,International Journal of Applied Engineering Research,V-9,I-22,P-7327-7335

13) Smitha M., Praveen Kumar S.,Understanding stress and it managementamong the nurses in Chennai city,2014,International Journal of Applied Engineering Research,V-9,I-22,P-7560-7565

14) Kerinab Beenu G.H., Praveen Kumar S.,A study on the investment behavior of Chennai investors in mutual fund schemes,2014,Internationa Journal of Applied Engineering Research,V-9,I-22,P-7520-7525

15) Loganathan R., Praveen Kumar S.,Retention strategies key for organizational productivity,2014,International Journal of Applied Engineering Research,V-9,I-22,P-7443-7447

16) Pavithra J., Ganesan M., Brindha G.,State wise analysis of microfinance sector in India,2016,International Journal of Pharmacy and Technology,V-8,I-4,P-23417-23432

17) Pavithra J., Ganesan M.,A comparative study on microfinance in India and abroad,2016,International Journal of Applied Business and Economic Research,V-14,I-8,P-5471-5476

18) Pavithra J., Ganesan M.,A study on awareness and impact of micro-financial schemes,2016,International Journal of Applied Business and Economic Research,V-14,I-8,P-5449-5460

19) Senthilmurugan P., Pavithra J.,Consumer preference towards organised retailing with reference to Big Bazaar,2014,International Journal of Applied Engineering Research,V-9,I-22,P-7469-7475

20) Senthilmurugan P., Pavithra J.,Implication of social media marketing in growing healthcare industry,2014,International Journal of Applied Engineering Research,V-9,I-22,P-7448-7456

21) Loganathan R., Pavithra J.,Consumer perception towards private label brand over other brands in super markets and hypermarkets,2014,International Journal of Applied Engineering Research,V-9,I-22,P-7355-7360

22) Kerinab Beenu G., Pavithra J.,Tradeâ€"off between liquidity and profitability in logistics industry,2014,International Journal of Applied Engineering Research,V-9,I-22,P-7398-740

23) Kerinab Beenu G., Pavithra J.,A study on the prospective consumerâ€ $€^{\mathrm{TM}_{\mathrm{S}}}$ perception towards utility cars in Chennai city,2014,International Journal of Applied Engineering Research,V-9,I-22,P-7526-7531

24) Pavithra J., Dilli Babu P., Ambuli T.V.,A study on budgetary control at Maruti Service Masters, Chennai,2014,International Journal of Applied Business and Economic Research,V-12,I-2,P-151-161

25) Pavithra J., Dilli Babu P., Ambuli T.V.,A study on customer satisfaction of retro Garments Pvt Ltd, Chennai,2014,International Journal of Applied Business and Economic Research,V-12,I-2,P-381-391

26) Kerinab Beenu G.H., Pavithra J., Senthilmurugan P.,A study on the influence of promotional activities for TATA ARIA among consumers in Chennai,2014,International Journal of Applied Engineering Research,V-9,I-22,P-7572-7578

27) Vijayaragavan S.P.,An investigative expert that's general FBG sensors,International Journal of Mechanical Engineering and Technology,V-8,I-8,PP-1500-1505,Y-2017

28) Vijayaragavan S.P.,Equalization routing protocol for $\mathrm{Wi}-\mathrm{Fi}$ senso strategy,International Journal of Mechanical Engineering and Technology,V-8,I-8,PP-1662-1666,Y-2017

29) Karthik B., Kiran Kumar T.V.U., Vijayaragavan P., Bharath Kumaran E.,Design of a digital PLL using 0.35 $11 / 4 \mathrm{~m}$ CMOS technology,Middle - East Journal of Scientific Research,V-18,I-12,PP-1803-1806,Y-2013

30) Kanniga E., Selvaramarathnam K., Sundararajan M.,Kandigital bike operating system,Middle - East Journal of Scientific Research,V

31) Jasmin M., Vigneshwaran T., Beulah Hemalatha S.,Design of power aware on chip embedded memory based FSM encoding in FPGA,International Journal of Applied Engineering Research,V-10,I-2,PP-4487-4496,Y-2015
32) Jasmin M.,Optimization techniques for low power VLSI circuits,Middle East Journal of Scientific Research,V-20,I-9,PP-1082-1087,Y-2014

33) Jasmin M., Vigneswaran T.,Fuzzy controller for error control of on - Chip communication,2017 International Conference on Algorithms, Methodology, Models and Applications in Emerging Technologies, ICAMMAET 2017,V-2017-January,I-,PP-1-5,Y-2017

\section{AUTHORS PROFILE}

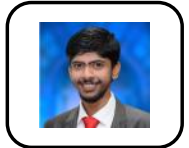

Gowtham ashirvad kumar Assistant Professor, Department of MBA, Bharath Institute of Higher Education and Research, Chennai, India.

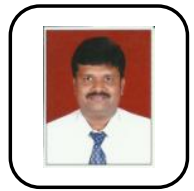

Dr . A. Ravi kumar Associate Professor, Department of THM, Bharath Institute of Higher Education and Research, Chennai, India. 